\title{
Peace economics in a changing world
}

\section{Raymond Gilpin}

Raymond Gilpin is Dean, Africa Center for Strategic Studies, National Defense University, Washington, D.C., USA. Prior to this, he was Associate Vice President, Economics, United States Institute of Peace, Washington, D.C., USA, where he managed the International Network for Economics and Conflict. He may be reached at raymond.gilpin@ndu.edu.

\section{Abstract}

Even though the global economy continues to grow and technological advancements expand horizons, over half of the world's population experiences profound want and fear on a daily basis. The global poor are predominantly found in countries that are underdeveloped and/or conflict-affected. Traditional economics has failed to provide an analytical framework that is both appropriate and transferrable, particularly in contexts where Westphalian assumptions of statehood do not hold true. Globalization, the rise of nonstate actors, and the existence of persistent low-intensity conflict have reconfigured the geostrategic landscape. By emphasizing the use of economic principles to promote peace through the design and implementation of strategies that foster efficiency and inclusion, peace economics could provide a viable framework for the development and security of fragile states and regions. This article examines the evolution of the discipline, analyzes potential challenges posed by fragile states, and proposes six recommendations for contemporary peace economists.

$\mathrm{E}$ ver since Adam Smith laid the discipline's intellectual foundations, economists have wrestled with the welfare implications of diverse approaches to the production, consumption, and distribution of wealth. After the first world war, economists such as John Maynard Keynes turned their attention to the relationship between government spending and the promotion of peaceful societal outcomes. A new discipline, dubbed peace economics, sought to distinguish itself from prevailing approaches that pursued peace by preventing violent conflict (the negative peace paradigm). By contrast, peace economics focuses on investments and relationships that promote lasting peace within and among nations (positive peace). The discipline has evolved over the decades. So has conflict. States, for instance, are no longer the main perpetrators of violence. Today, most violence-affected states are fragile and nonstate actors play a central role in twentyfirst century conflicts. Globalized threats and transnational crime are prominent in triggering and sustaining violent conflict. These developments challenge our thinking about the role and application of peace economics, particularly in fragile environments. In 2003, Fischer and Brauer posed twenty questions for peace economists to address in the post-Berlin Wall era. Just as scholars and practitioners struggled to make sense of the relevance of this discipline at that strategic juncture, so global realities today force us to revisit and rethink the role of peace economics in a changing world. This article views the challenge through the prism of developing and conflict-affected countries. ${ }^{1}$

\section{Revisiting definitions}

Although many point to the classical economists of the eighteenth and nineteenth centuries who theorized that free trade is peace-enhancing, there is some consensus that the work of Kenneth Boulding, Johan Galtung, Walter Isard, and Jan Tinbergen laid the foundation for peace economics as we know it today. By distinguishing positive from negative peace, Galtung differentiated the nascent field from war or defense economics. He pointed out the need for countries to make strategic investments that promote peace, equity, and welfare rather than focusing on prosecuting and stopping wars (negative peace). In this vein, peace economics may be viewed as the study of strategic investments by the state that further and promote positive peace. Extensions of this view include the distinction between productive and unproductive expenditures. Isard's work focused on the use of economic instruments to forestall violent conflict and the impact of economic policy (by governments) and economic activity (by firms) on the prospects for violent conflict. Nobel Laureate Tinbergen also belongs to this "behaviorist" school of thought, defining peace economics as a science that seeks to understand how global and interstate conflict may be resolved using economic principles and instruments. Boulding's systems approach represents a third category of definitions. He viewed the discipline as a set of complex interrelationships that yield positive peace. Looking beyond the classification of productive expenditures or activities, he sought a more integrated set of actions and policies that establish the conditions for more peaceful societies. With traditional peace economists the emphasis is less 
on analyzing existing and emerging complexities and more on hypothesizing what a peaceful world should look like. Using their hypothesized peaceful world, they outline how state expenditure could invest toward that end. ${ }^{2}$

The 1990s witnessed the genesis of an evolution in peace economics. Building on existing normative frameworks, scholars highlighted the importance of an applied approach that seeks to build institutions and establish policies that promote peace and stability. Brauer and Caruso defined the subject matter as follows: "Peace economics concerns the economic study and design of political, economic, and cultural institutions, their interrelations, and their policies to prevent, mitigate, or resolve any type of latent or actual destructive conflict within and between societies." In their view, "peace economics is not primarily about the prevention of (state or communal) failure ... but about the creation of stable structures of peace. It is about invulnerability, irreversibility and about the foolproof, unconditional viability of peaceful social systems." In a separate piece, Caruso goes further and discusses how peace economics could be pivotal in the design of governance, trade, and social investment policies that are peace-promoting. The post-1990s evolution of peace economics shifted the focus away from what was essentially a binary "guns versus butter" debate to a more complex consideration of elements of an enabling framework for sustained peace. ${ }^{3}$

\section{Recalibrating in conditions of fragility}

A fundamental ethos of traditional peace economics was the ability of the state or state institutions to invest in peaceful outcomes. Post-1990s thinking went beyond this and analyzed systems (institutions and policies) that act jointly to promote peace. At a national level, the state is still a central actor. The state's ability to support peace-promoting investments, infrastructure, and institutions is crucial. States that fail to meet this litmus test are broadly described as fragile.

What happens, however, when the state is unable or unwilling to perform this function? Inability is caused by weak institutions, ineffective regulatory and legislative frameworks, endemic poverty, and significant capacity gaps. The vast majority of developing countries and conflict-affected states fall into this category. They lack the capacity to invest in socioeconomic services, infrastructure, and human capital that would not only make communities and states more resilient but could also promote peace. This inability reinforces fragility and weakens the state further. Fragile states are particularly susceptible to continued outbreaks of civil unrest and violent conflict. In other cases, fragility manifests itself in the unwillingness of states to make the necessary peace-promoting
Just as scholars and practitioners struggled to make sense of the relevance of peace economics in the post-cold war era, so new global realities today force one to revisit and rethink its role. From a peace practitioner's point of view, this article revisits and challenges extant definitions of peace economics and makes recommendations on how to broaden its scope to make it more relevant for today's changing world.

investments. Such states might have the capacity but are unwilling to invest in transformational change. This unwillingness could stem from political considerations, where illegitimate regimes invest in their own security and longevity and not in the broader society. Leaders of such states sit at the apex of a neo-patrimonial network that defines governance, economics, and security in the state. For them, public sector investments are viewed as zero-sum propositions that must always favor their own interests and longevity. Apartheid South Africa and Mobutu's Zaire are examples. In either case (inability or unwillingness) the result is similar. State fragility becomes entrenched and countries end up spending more on fomenting or addressing violent conflict rather than on investing in peace. Marshall describes the far-reaching implications of fragility. The potential demise of peace economics, as originally construed, should be added to Marshall's list. ${ }^{4}$

The concept of fragility has evolved since the Fragile States Index was first published in Foreign Policy magazine in 2005. The initial focus on fragile states has given way to a more appropriate investigation of the states or conditions of fragility as reported in the 2016 edition of the Organization for Economic Cooperation and Development's annual report on state fragility. The focus has shifted from exclusively national institutions to subnational and transnational conditions and institutions. Major implications include the notions that nonfragile states can also harbor fragile regions and host fragile communities, that fragility could straddle one or more national boundaries, and that remediating and mitigating policy and programs should focus on the nature of fragility and not just on nation-building. This poses challenges for peace economics, if the discipline were to remain state-centric. The complexities of contemporary statehood, coupled with the transnational nature of violent conflict, demand a serious rethinking of the sources, nature, and focus of peace-promoting expenditure. It also poses questions about the reliability and efficacy of public sector institutions in fragile states to make the necessary investments. ${ }^{5}$

\section{Challenges for practitioners}

Adjusting for fragility is necessary but by no means sufficient. Peace economists face complex and persistent challenges, including incorporating into their analyses (1) persistent 
low-intensity conflicts, (2) the peacebuilding-industrial complex, (3) pervasive Potemkin institutions, and (4) the role of nonstate actors.

War and peace no longer are two sides of the same coin. Today, they coexist of an ever-mutating, multi-sided structure. Since the mid-1990s, violent conflict does not just disappear. Instead, it recedes. This leaves communities and countries in a seemingly endless state of low-intensity conflict. Very few contemporary violent conflicts have had clear winners and losers. The vast majority of peace deals are about forging compromise with actors who do not usually have a stake in building peaceful and stable states. In many cases, such as in post-war Liberia from 2003 to 2005 and in post-invasion Afghanistan, the key actors appear to have little interest in peace-promoting investments. The consequent persistent low-intensity conflict causes at least two problems. First, nations (and their international partners) tend to focus most of their energies on preventing the recurrence of war rather than on building peace. Second, these states have problems defining effective peacebuilding strategies and consequently anemic domestic economies struggle to keep pace with the demand for public expenditures. ${ }^{6}$

Peacebuilding has become a global industry that commandeers entire economies and reshapes the security environment in many countries. In some cases United Nations deployments become dominant ecosystems in host countries. For instance, the UN deployment in the Democratic Republic of the Congo (known by its French acronym, MONUC) has existed for sixteen years, at an estimated cost of over USD10 billion. Planned MONUC spending for the 2016/17 fiscal year was USD1.2 billion, corresponding to about 20 percent of the host nation's annual budget spending. Analysts have questioned the impact that such deployments could have on domestic counterpart funding (crowding out such spending) and on the perpetuation of the peacekeeping enterprise. Similarly, the United States defense department created the Task Force for Business and Stability Operations in 2006 to kick-start peacebuilding efforts initially in Iraq and subsequently in Afghanistan. Multimillion dollar initiatives like these were known more for their "burn rate" (i.e., how much money they could spend in a given period) than for their effectiveness and impact. Peace prospects are further complicated in that conflict-affected states suffer from a war-economy overhang (when warlords capture the post-war economy). Therefore, rapid, and often unfocused, spending ends up in the coffers of potential spoilers who use these resources to strengthen and sustain perverse neo-patrimonial networks. ${ }^{7}$

External partners and institutions play a crucial role in conflict-affected states, leading to overly aid-dependent states. By relying on development assistance for most fiscal outlays, conflict-affected countries effectively cede sovereignty to their external partners. They lose the ability to prioritize expenditures, determine the timing and quantum of inflows, develop alternative domestic revenue sources, and develop much-needed, credible multi-year investment strategies. Commercial entities also feature in this context since most developing and conflict-affected states are resource-endowed. International firms investing in these countries also play a role in determining the extent to which states are willing or able to make peace-enhancing investments. Investors engage the domestic political economy in order to maximize profits, ensure the long-term viability of their capital investments, and to accelerate the onset of the break-even point as a risk mitigation strategy. In many cases, this dynamic is itself conflictinducing. ${ }^{8}$

Peace economists also have to consider the proliferation of nongovernmental organizations (NGOs) in developing and conflict-affected states. Proliferation can create duplication, undermine coordination, introduce conflicting agendas, and add confusion to an already weakened policy environment. More perniciously, it can weaken the public sector by crowding-out the labor market, reinforcing neo-patrimonial networks, and promoting niche projects at the expense of a more comprehensive effort to invest in peace. There is an urgent need to incorporate the nature, character, scope, and objectives of nonstate actors (like NGOs) when considering how best to develop a framework of institutions and relationships that could advance a peace-promoting agenda in developing and conflict-affected states. ${ }^{9}$

\section{Some recommendations}

Contemporary peace economics could play an important role in shaping governance and economic development outcomes in fragile regions and nations. The following recommendations outline aspects of what may be described as an unfinished agenda for peace economists.

First, Boulding's comment that "all economics is peace economics and all economists are peace economists" is not particularly useful. The discipline needs more definitional specificity if it is going to have normative or functional utility. Reconceptualizing peace economics in the light of contemporary statehood, transnational phenomena, and the growing influence of nonstate actors is both, urgent and necessary.

Second, reconceptualizing peace economics is not an easy task. It is going to require both, a transition from a normative to a more functional focus as well as significant empirical research 
into the relationships between peace-promoting investments and corresponding peaceful outcomes. The 2011 World Development Report helped bridge the gap between economic outcomes and persistent violent conflict. It also mainstreamed the issue in policy circles. Peace economics needs a similar catalyst.

Third, very few tertiary educational institutions offer courses in peace economics. Consequently, the profession is left floundering and forced to borrow extensively from related disciplines when designing policy and operational initiatives aimed at supporting peace-promoting programs. Efforts should be made to introduce courses and degree-awarding programs to build capacity in this area. This should also be done in professional military institutions since uniformed personnel are often the first responders who get assigned the development and implementation of peace-promoting initiatives in conflict-affected regions.

Fourth, investing in peace involves much more than the state. More attention should thus be paid to the role of nonstate actors, including nongovernmental organizations, local firms, and multinational corporations. Ensuring coordination, alignment, and sustainability should be prioritized to ensure lasting positive impact. Relevant programs and activities should be nested within an overarching theory of how strategically sequenced investments by all actors could ensure equitable economic progress, effective and accountable political institutions, and lasting peace.

Fifth, external partners (commercial, bilateral, multilateral, and sociocultural) play an important role in developing and conflict-affected states. Peace economics could incorporate these actors into a cogent theoretical framework in a much more deliberate fashion. The notion that states alone should take the lead in the initial phases of recovery and rebuilding is not borne out by the available evidence. In addition, external partners should have a clear exit strategy that involves weaning states off the dependency syndrome.

Sixth, domestic revenue generation is a vital, although frequently neglected, aspect of the social contract. Taxation binds the governed and their governments in terms of expectations and accountability. Aid-dependent states are much less likely to be accountable to their citizens. Rebuilding or establishing a social contract could start by enhancing the tax effort and, in turn, strengthening accountability.

\section{Conclusion}

Peace economics could deepen our understanding of the development-security nexus and help refocus economic policy on the promotion of positive peace. A peace-promoting agenda could strengthen institutions and advance policies that address inequality, foster accountability, and reduce the factors that trigger and sustain violent conflict. This is especially true in developing and conflict-affected states. To accomplish this, the discipline should continue to adapt and evolve. Recent developments in theory should be driven by an increase in empirical research, educational courses and curricula could be expanded, and customized training opportunities should be made available to a broad array of practitioners. Failure to make progress in these areas could condemn millions of people to protracted deprivation and misery, and could confine peace economics to the pages of history in some distant ivory tower.

\section{Notes}

Disclaimer: The views expressed in this paper are those of the author and are not an official policy or position of the National Defense University, the Department of Defense, or the U.S. Government.

1. State no longer main perpetrator: Data from the Uppsala Conflict Data Program (UCDP) shows the reduction in the number of state-based, battle-related deaths relative to nonstate and one-sided violence deaths between 1980 and 2016. See http:/ucdp.uu.se/. Likewise, data from the Armed Conflict Location and Event Data project (ACLED) paints a similar picture for 1997 to 2016 . See http://www.acleddata.com/data/ acled-version-7-1997-2016/. Post-Berlin Wall: Fischer and Brauer (2003).

2. Boulding (1970); Galtung (1982); Tinbergen (1990); Isard (1994).

3. Quotes: Brauer and Caruso (2013, pp. 151-152; 153). In a separate piece: Caruso (2015).

4. Neo-patrimonial: The nature and characteristics of such networks are discussed in Gilpin (2015). Implications of fragility: Marshall (2008).

5. Foreign Policy (2005). OECD (2016).

6. Liberia, Afghanistan: See, e.g., Del Castillo (2008).

7. MONUC: See http://www.un.org/en/peacekeeping/missions /past/monuc. U.S. Task Force: See Zimmerman, Engel, and Blum (2016).

8. External partners: This is well-documented in Del Castillo (2008).

9. NGO proliferation: By way of example, Klarreich and Polman (2012) and Baptiste (2015) examine the NGO proliferation phenomenon in Haiti after the 2010 earthquake there.

\section{References}

Baptiste, N. 2015. "Are Foreign NGOs Rebuilding Haiti Or Just Cashing In?” Foreign Policy in Focus. 10 July 2015. http://fpif.org/are-foreign-ngos-rebuilding-haiti-or-just-ca shing-in/.

Boulding, K.E. 1970. "Economics as a Social Science," pp. 
1-22 in K.E. Boulding. Economics as a Science. New York: McGrawHill.

Brauer, J. and R. Caruso. 2013. "Economists and Peacebuilding," pp. 147-158 in Roger Mac Ginty, ed. Handbook of Peacebuilding. London: Routledge.

Del Castillo, G. 2008. Rebuilding War-Torn States: The Challenge of Post-Conflict Economic Reconstruction. Oxford, UK: Oxford University Press. https://doi.org/10.1093/acprof:oso/9780199237739.001.0001

Caruso, R. 2015. "Beyond Deterrence and Decline Towards a General Understanding of Peace Economics." Rivista Internazionale di Scienze Sociali. No. 1, pp. 57-74. https://doi.org/10.2139/ssrn.2607897

Fischer, D. and J. Brauer. 2003. "Twenty Questions for Peace Economics." Defence and Peace Economics. Vol. 14, No. 3, pp. 223-236. https://doi.org/10.1080/1024269022000000831

Foreign Policy Magazine and the Fund for Peace. 2005. The Failed State Index 2005 . Se e $\mathrm{http} / /$ foreignpolicy.com/2009/10/22/the-failed-states-ind ex-2005/.

Galtung, J. 1982. Environment, Development and Military Activity. Towards Alternative Security Doctrines. Oslo: Norwegian Universities Press.

Gilpin, R. 2015. "Economic Drivers of Mass Atrocities: Implications for Policy and Prevention." Stanley Foundation Policy Brief. https://www.stanleyfoundation. org/publications/pab/GilpinPAB815.pdf.

Isard, W. 1994. "Peace Economics: A Topical Perspective." Peace Economics, Peace Science and Public Policy. Vol. 1, No. 2, pp. 11-13.

Klarreich, K. and L. Polmam. 2012. "The NGO Republic of Haiti." The Nation. 31 October 2012. https://www.thenation.com/article/ngo-republic-haiti/.

Marshall, M.G. 2008. "Fragility, Instability and the Failure of States: Assessing Sources of Systemic Risk." Working Paper. Council on Foreign Relations. https://www.cfr.org/sites/default/files/report_pdf/CPA WorkingPaper_1.pdf .

OECD. 2016. "States of Fragility 2016: Understanding Violence." Paris: OECD Publishing. http://dx.doi.org/10.1787/9789264267213-en

Tinbergen, J. 1990. World Security and Equity. Aldershot, UK: Elgar.

Zimmerman, S.R., D. Engel, and I. Blum. 2016. "Task Force for Business and Stability Operations: Lessons from Afghanistan." St. Monica, CA: Rand Corporation. https://www.rand.org/content/dam/rand/pubs/research_re ports/RR1200/RR1243/RAND_RR1243.pdf.

https://doi.org/10.7249/RR1243 